\title{
PERSOALAN PELESTARIAN BAHASA CIACIA: REFLEKSI ATAS ETIKA DISKURSUS*)
}

\section{THE PROBLEM IN CIACIA LANGUAGE PRESERVATION: REFLECTIONS ON DISCOURSE ETHICS}

\author{
Mikka Wildha Nurrochsyam \\ Pusat Penelitian dan Kebijakan Pendidikan dan Kebudayaan, Balitbang, Kemdikbud \\ JIn Jenderal Sudirman-Senayan, Gedung E Lantai 19, Jakarta 12041 \\ e-mail: mikkawildha@yahoo.com
}

Naskah diterima tanggal: 22/02/2015, Direvisi akhir tanggal: 31/04/2015, disetujui tanggal: 06/08/2015

\begin{abstract}
Ciacia language is the language used by the Ciacia community in Southeast Sulawesi. In August 2009, the Mayor of Baubau, Southeast Sulawesi, enacted policy to adapt the Korean alphabet (Hangeul) into the Ciacian alphabet because the Ciacia language does not have its own script. This decision immediately caused controversy as some agreed and others disagreed. This paper has two objectives. First, it seeks to observe the diverse opinions surrounding the decision to adapt the Korean alphabet into the Ciacia alphabet. Secondly, the paper offers a reflection on the ethical discourse surrounding the adaptation of the Korean alphabet into the Ciacia alphabet. This study used case studies and took a qualitative approach. Results showed that there was not enough support given to the public to encourage practical discourse and offer a no-pressure environment. Support was neither given within the Ciacia community in Baubau nor outside Baubau to strengthen Ciacia language and culture. This study concluded that those who agree with the adaptation are likely to understand it as serving an instrumental function in furthering economic and political interests. Meanwhile, those who oppose the adaptation are more concerned with culture preservation. Proper discourse has not taken place in regards to this issue. Thus, the debate continues to be unresolved.
\end{abstract}

Keywords: language preservation, discourse ethics, Ciacia language

\begin{abstract}
Abstrak: Bahasa Ciacia merupakan bahasa yang digunakan oleh masyarakat Ciacia di Sulawesi Tenggara. Walikota Baubau, Sulawesi Tenggara pada Agustus 2009 memutuskan kebijakan mengadaptasi aksara Korea (Hangeul) menjadi aksara Ciacia karena Bahasa Ciacia tidak mempunyai aksara sendiri. Keputusan ini menimbulkan reaksi baik pro maupun kontra. Tulisan ini mempunyai dua tujuan Pertama, ingin mengetahui pendapat-pendapat tentang kasus adaptasi aksara Korea menjadi aksara Ciacia. Kedua, ingin mengetahui implementasi etika diskursus untuk menyelesaikan kasus adaptasi aksara Korea menjadi aksara Ciacia. Penelitian ini menggunakan pendekatan kualitatif dengan metode studi kasus. Hasil penelitian menunjukan bahwa kasus adaptasi ini kurang memberikan ruang publik untuk diskursus praktis dalam suasana saling pengertian dan bebas dari tekanan, baik dalam masyarakat Ciacia di wilayah Kota Baubau maupun masyarakat Ciacia di luar Kota Baubau sebagai pendukung bahasa dan budaya masyarakat Ciacia. Penelitian ini menyimpulkan bahwa pihak yang pro adaptasi lebih cenderung berorientasi pada rasionalitas instrumental yakni kepentingan ekonomis dan politis, sedangkan pihak yang kontra berorientasi pada pelestarian budaya. Dalam kasus adaptasi ini belum diterapkan etika diskursus secara memadai sehingga tetap menjadi perdebatan yang tak terselesaikan.
\end{abstract}

Kata Kunci: pelestarian bahasa, etika diskursus, bahasa Ciacia 


\section{PENDAHULUAN}

Pada era orde baru kebijakan kebudayaan cenderung menempatkan kekuasaan negara lebih dominan karena mempunyai kekuasaan penuh mengatur urusan kebudayaan warganya. Seperti ditulis oleh Jones (2005), dalam disertasinya mengutip pendapat Supartono bahwa pada orde baru yang muncul berjaya yaitu kebudayaan militer. Upacara dan barisberbaris, indoktrinasi Pedoman Penghayatan dan Pengamalan Pancasila (P4), penyeragaman kurikulum, asas tunggal dalam politik, dan pelarangan kegiatan kesenian bagi etnis Tionghoa merupakan beberapa contoh dari kuatnya semangat militerisme dalam budaya selama tiga dekade terakhir.

Era reformasi di Indonesia ditandai dengan kekuasaan yang tidak lagi terpusat. Peran pemerintah pusat yang sentralistik digantikan dengan sistem baru yang lebih bersifat desentralisasi. Demokratisasi di tingkat subnasional ini dikenal dengan desentralisasi dan otonomi daerah. Desentralisasi merupakan penyerahan wewenang oleh pemerintah pusat kepada daerah otonom untuk mengatur dan mengurus urusan pemerintahan dalam sistem Negara Kesatuan Republik Indonesia.

Di era reformasi Indonesia memasuki babak baru dalam tatanan sosial dan pemerintahan yang lebih baik. Indonesia menjadi lebih demokratis tetapi di sisi lain telah menimbulkan problem di berbagai bidang termasuk persoalan pelestarian budaya. Sekitar tahun 2010 masyarakat dunia berpaling kepada kelompok kecil masyarakat Ciacia di Kota Baubau, karena walikota Baubau pada saat itu telah menetapkan keputusan kontroversial untuk mengadaptasi aksara Korea (Hangeul) menjadi aksara Ciacia - yang selanjutnya dikenal sebagai aksara yang sudah terpengaruh oleh Hangeul. Adaptasi ini dilatarbelakangi oleh permasalahan tentang bagaimana melestarikan bahasa daerah yang bertebaran di seluruh penjuru kota Baubau.

Bahasa Ciacia merupakan bahasa tutur yang digunakan oleh masyarakat Ciacia. Penutur bahasa Ciacia kurang lebih 93.000 penutur.
Jangkauan pengguna bahasa Ciacia tersebar di antaranya di Pulau Buton terdapat di Sampolawa, Pasarwajo, Wabula dan beberapa wilayah lainnya. Di Kota Baubau digunakan oleh masyarakat Ciacia di Kecamatan Sorawolio, antara lain di kelurahan Gonda Baru, Karya Baru, dan Kaisabu Baru. Di Kabupaten Wakatobi, bahasa Ciacia digunakan di Kecamatan Binangko, yang meliputi beberapa kelurahan antara lain, kelurahan Wali, Desa Jaya Makmur. Bahasa Ciacia juga digunakan oleh penutur di beberapa tempat di luar Pulau Buton, sesuai dengan penyebaran masyarakat Ciacia, seperti di Pulau Buru di Desa Pasir Putih; Maluku Utara, Pulau Seram, Bangka Belitung bahkan penyebaran sampai ke Maumere (Alirman, 2010).

Masyarakat Ciacia tidak memiliki budaya tulis. Satu-satunya tradisi tulis masyarakat Ciacia ditemukan dalam kutika, yaitu semacam coretan-coretan yang ditorehkan pada sepotong papan kayu atau kertas yang mirip sebagai simbol, untuk meramalkan nasib, atau keberuntungan. Kutika juga digunakan untuk menentukan waktu musim tanam; sampai digunakan untuk meramalkan tim mana yang menang dalam pertandingan sepak bola. Tidak semua orang mempunyai kutika, pada umumnya dimiliki oleh orang yang dituakan dalam masyarakat (La Ali, wawancara, 18 Desember 2013).

Kebijakan menggunakan aksara Korea bermula dari sebuah Simposium Internasional Pernaskahan ke-9 pada 5-8 Agustus 2005. Seusai simposium, ketika para peserta melakukan wisata keliling kota, Chun Tai-Hyun, seorang ahli Bahasa Malaysia dan sekaligus sebagai Ketua Departemen Hunmin Jeonggeum Masyarakat Korea, bercanda bahwa bahasa lokal yang didengarnya di sini mengingatkan pada Korea. Dikatakannya bahwa aksara Hangeul dapat digunakan sebagai aksara untuk bahasa Ciacia yang sedang mengalami kepunahan. Pernyataan Chun Tai-Hyun segera direspon positif oleh Walikota Baubau (Song, 2013).

Penelitian terkait dengan adaptasi aksara Korea menjadi aksara Ciacia telah dilakukan oleh 
beberapa ahli. Di antaranya dilakukan oleh Song (2013), yang meneliti tentang motif-motif di balik adaptasi aksara Korea. Hasil penelitian menunjukkan bahwa bagian pinggiran Indonesia telah mencoba untuk membentuk identitasnya sendiri sebagai entitas yang berbeda sebagai kelompok orang yang tinggal dalam sebuah Negara. Upaya ini dilakukan dengan harapan untuk menunjukan pusat baru di dalam desentralisasi di Indonesia.

Penelitian lain, dilakukan oleh Hanan (2014) - dalam disertasinya yang berjudul: "Genealogi Bahasa Ciacia" - meneliti tentang pengaruh bahasa lokal yang mempengaruhi bahasa Ciacia. Hasil penelitiannya menunjukan bahwa wilayah tutur bahasa Ciacia di bagian selatan Pulau Buton, diketahui telah mendapat pengaruh dari bahasa Busoa, Muna, dan Wolio; bahasa Ciaca yang dipakai masyarakat di bagian timur Pulau Buton mendapat pengaruh dari bahasa Lasalimu dan bahasa Kamaru; Bahasa Ciacia yang digunakan masyarakat di Pulau Binongko mendapat pengaruh bahasa Wakatobi; dan bahasa Ciacia di kecamatan Sorawolio, Kota Baubau mendapat pengaruh bahasa Wolio. Kalau melihat hasil penelitian ini dapat dikatakan bahwa bahasa Korea tidak ada pengaruhnya terhadap bahasa Ciacia.

Penelitian yang dilakukan berbeda dengan penelitian sebelumnya oleh Song maupun Hanan. Penelitian Song misalnya, melihat aspek motifmotif dalam adaptasi aksara Korea sedangkan penelitian Hanan melihat pengaruh bahasa tutur lokal yang berpengaruh pada bahasa Ciacia; sedangkan penelitian yang penulis lakukan ingin meneliti sebuah problem yang muncul dalam pelaksanaan otonomi daerah yakni problem kebijakan pelestarian budaya, yang mengalami perubahan mendasar semasa Era Reformasi. Pada masa Orde Baru kebijakan kebudayaan cenderung bersifat deskriminatif, misalnya dengan dikeluarkannya Instruksi Presiden Nomor 14 Tahun 1967 yang melarang semua kegiatan keagamaan, kepercayaan dan kebudayaan Tiongkok; serta Surat Edaran Presidium Kabinet Ampera Nomor 06 Tahun 1967 yang mengubah kata "Tionghoa" menjadi "Cina". Di era Reformasi pemerintah daerah mempunyai kewajiban untuk melestarikan nilai sosial budaya dalam rangka sistem negara kesatuan Indonesia. Namun, tidak jarang kebijakan budaya tersebut memunculkan persoalan baru di bidang pelestarian budaya. Kewajiban untuk melestarikan budaya diinterpretasikan secara berbeda oleh pemerintah daerah. Secara khusus penelitian ini melihat kasus adaptasi aksara Korea dalam perspektif etika diskursus, yakni melihat bagaimanakah konsesus tanpa tekanan dalam suasana pengertian dilakukan secara adil untuk keberterimaan aksara Korea dari pendukung bahasa Ciacia. Sampai saat penelitian tentang adaptasi Korea dalam perspektif etika diskursus belum ada yang melakukan, karena itu tulisan ini benarbenar asli.

Penelitian ini menjadi penting karena memperhatikan keniscayaan bahwa Indonesia terdiri dari beragam suku bangsa dan kelompok masyarakat dengan keanekaragaman budaya, seperti tradisi, kepercayaan, rumah adat, seni tradisional, dan beragam karya-karya budaya yang eksotik. Dalam relasi sosial, masing-masing etnis dan kelompok masyarakat menjalin komunikasi dan interaksi. Di satu sisi terjalin hubungan yang harmonis. Masyarakat mengembangkan sikap saling menghargai, toleransi dan solidaritas. Di sisi lain, terjadi perbenturan kepentingan dan identitas. Penelitian ini menjadi penting karena berupaya mencari solusi yang memadai untuk mencapai kesepakatan dalam mengadaptasi sebuah budaya asing dalam kultur budaya lokal di Indonesia dengan baik dan adil sehingga disharmoni dalam masyarakat bisa dihindarkan.

Berdasarkan uraian di atas dirumuskan permasalahan penelitian sebagai berikut: 1) bagaimanakah pendapat masyarakat pendukung budaya Ciacia mengenai kasus adaptasi aksara Korea menjadi aksara Ciacia yang dilakukan oleh pemerintahan Kota Baubau?; dan 2) Bagaimanakah implementasi etika diskursus untuk menyelesaikan kasus adaptasi aksara Korea menjadi aksara Ciacia? Koheren dengan 
permasalahan tersebut dirumuskan tujuan penelitian yaitu: 1) mengetahui pendapat masyarakat pendukung budaya Ciacia mengenai kasus adaptasi aksara Korea menjadi aksara Ciacia yang dilakukan oleh pemerintahan Kota Baubau; dan 2) mengetahui tentang implementasi etika diskursus untuk menyelesaikan kasus adaptasi aksara Korea menjadi aksara Ciacia.

\section{KAJIAN LITERATUR}

\section{Aksara dan Bahasa}

Dalam Kamus Besar Bahasa Indonesia kata "aksara" mempunyai tiga arti; pertama berarti "sistem tanda grafis yang digunakan manusia untuk berkomunikasi dan sedikit banyak mewakili ujaran; kedua berarti jenis sistem tanda grafis tertentu; dan ketiga berarti huruf. Selanjutnya, secara etimologi, asal-mula kata "aksara' berasal dari bahasa Sanskerta yang terdiri dari dua suku kata yaitu "a" dan "kshara." Kata "a" memiliki arti 'tidak,' sedangkan "kshara" berarti "termusnahkan". Jadi, kata "aksara" mempunyai arti "tidak termusnahkan". Istilah ini mengacu pada pengertian bahwa aksara sebagai alat untuk mendokumentasikan budaya atau peristiwa sehingga peristiwa atau budaya itu dapat langgeng.

Di nusantara pernah digunakan beberapa aksara untuk menuliskan bahasa, diantaranya adalah aksara Jawa yang digunakan untuk menuliskan bahasa Jawa. Aksara Batak digunakan untuk menuliskan bahasa Batak dengan variasi antara lain: aksara Batak Toba untuk menuliskan Bahasa Toba; aksara Batak Karo untuk menuliskan bahasa Karo; aksara Simalungun untuk menuliskan bahasa Simalungun dan aksara Mandailing untuk menuliskan bahasa Mandailing. Aksara Bali untuk menuliskan Bahasa Bali; dan aksara Lontara dengan variasinya seperti aksara Bugis merupakan aksara Lontara untuk menuliskan bahasa Bugis; aksara Makassar untuk menuliskan bahasa Makassar Aksara Arab juga digunakan untuk menuliskan bahasa Jawa dan Sunda sedangkan di Pulau
Buton dikenal aksara Buri Wolio untuk menuliskan bahasa Wolio.

Banyak kelompok masyarakat memiliki budaya dengan bahasa khas tetapi seringkali tidak mempunyai aksara tulis sendiri sehingga untuk menuliskan bahasa yang mereka miliki digunakan aksara lain, seperti aksara Arab, atau yang paling sering adalah aksara Latin. Masyarakat Ciacia sebagai pendukung bahasa Ciacia tidak mempunyai aksara tersendiri, sehingga mereka perlu meminjam aksara lain. Aksara Latin merupakan aksara yang paling umum digunakan untuk menuliskan bahasa Ciacia, tetapi tidak jarang juga digunakan aksara Arab yang sudah diadaptasi oleh masyarakat Buton, yakni aksara Buri Wolio. Dalam kasus ini, secara resmi pemerintah daerah Baubau pada waktu itu mengambil keputusan mengadaptasi aksara Korea yang diklaimnya sebagai bentuk pelestarian bahasa Ciacia dari kemusnahan.

\section{Melestarikan Bahasa Melestarikan Budaya}

Budaya mempunyai definisi yang beragam, diantaranya Tylor dalam Kusumohamidjojo (2009) mengatakan bahwa budaya adalah kompleks keseluruhan yang termasuk pengetahuan, kepercayaan, moral, hukum, kebiasaan dan kemampuan manusia yang lainnya serta kebiasaan yang diperoleh manusia sebagai anggota kelompok masyarakat. Lebih lanjut, Linton dalam Kusumohamidjojo (2009) berpendapat bahwa kebudayaan merupakan jumlah total pengetahuan, sikap-sikap, pola kebiasaan tindakan yang dishare dan ditransmisikan oleh anggota masyarakat tertentu. Linton memperlihatkan bahwa masyarakat pendukung kebudayaan sangat penting. Karena itu, budaya tergantung bagaimana peran masyarakat pendukungnya. Antara budaya dan masyarakat pendukungnya tidak dapat dipisahkan. Sebuah budaya yang berasal dari luar bisa jadi tidak didukung oleh sebuah kelompok masyarakat karena dianggap bukan menjadi karakter masyarakat pendukungnya. 
Aksara sebagai karya cipta manusia dapat dipandang sebagai kemampuan intelektual sebuah komunitas masyarakat. Kalau dilihat dari pendapat Taylor, budaya tidak statis tetapi mengalami perkembangan, karena ada share dan transmisi dari anggota pendukungnya. Aksara juga tidak statis tetapi mengalami perkembangan, karena aksara dishare dan ditransmisikan dari generasi ke generasi, sedikit banyak tentu mengalami perkembangan. Namun, yang terpenting dalam kebudayaan itu perlu memperhatikan sikap dan peran masyarakat pendukungnya. Adaptasi terhadap budaya lain selain menunjukan bahwa kebudayaan itu tidak statis sekaligus perlu mempertimbangkan keberterimaan masyarakat pendukungnya.

Budaya dapat berkembang tetapi dapat juga mengalami penurunan dan bahkan kepunahan. Karena itu, terdapat kebijakan dari pemerintah untuk pelestarian budaya, seperti Peraturan Menteri Dalam Negeri Nomor 39 Tahun 2007 tentang Pedoman Fasilitasi Organisasi Kemasyarakat Bidang Kebudayaan, Keraton dan Lembaga Adat dalam Pelestarian dan Pengembangan Budaya Daerah, disebutkan bahwa pelestarian budaya daerah merupakan upaya untuk memelihara sistem nilai sosial budaya yang dianut oleh komunitas/kelompok masyarakat tertentu di daerah, yang diyakini di dalamnya terdapat nilai-nilai, sikap serta tata cara masyarakat yang dapat memenuhi kehidupan warga masyarakat. Persoalannya adalah bagaimanakah pemerintah daerah menginterpretasikan pelestarian budaya daerah. Upaya untuk pelestarian budaya seringkali menimbulkan perbedaan tafsir dan kontroversi.

Menurut Elis (2005) terdapat dua argumen mengapa pelestarian bahasa menjadi penting. Pertama karena anggapan bahwa bahasa merupakan bagian penting dari budaya, tanpa bahasa, budaya tidak mungkin ada. Kedua, anggapan bahwa setiap orang sangat tergantung pada integritas budaya mereka masing-masing untuk membangkitkan pengakuan terhadap budayanya.
Karena pentingnya bahasa, beberapa negara berupaya melakukan pelestarian bahasabahasa lokal yang sedang mengalami kepunahan. Seperti di Peru upaya pelestarian bahasa juga memunculkan kontroversi. Serafýn (2008) menuliskan tentang upaya The High Academy of the Quechua Language, salah satu organisasi yang berkomitmen untuk melestarikan bahasa Quechua juga tidak lepas dari kritik pihak lain. Upaya pelestarian oleh lembaga ini justru dianggap menghambat agen-agen lain dan para ahli yang sama-sama mempromosikan bahasa Quechua. Organisasi ini juga dianggap diresapi nilai-nilai kelompok yang justru mengalineasi orang-orang berbahasa Quechua sendiri yang notabene ingin mereka layani.

Davis (2013) juga memaparkan tentang pentingnya pelestarian bahasa, sehingga negara bagian Montana - USA, menciptakan program untuk membantu pelestarian bahasa-bahasa lokal. Proyek pelestarian bahasa ini memberikan bantuan 2 milyar dollar kepada beberapa masyarakat lokal agar dapat menciptakan, merekam dan mengembangkan materi-materi dan menciptakan kurikulum untuk menjaga agar bahasa tutur mereka tidak mengalami kepunahan.

Pelestarian bahasa yang berhasil dapat dilihat dari kebijakan pemerintah Myanmar dengan mengenalkan kurikulum baru bahasa dan tulisan Karenni kepada peserta didik di wilayah tersebut, setelah ditetapkan oleh keputusan majelis di Negara bagian Loikaw. Pengajaran anak-anak Karenni dengan bahasa ibu itu telah didukung oleh 80 persen masyarakat lokal dalam sebuah survei lapangan. Karena itu, pengajaran bahasa Karenni tidak akan menjadi problem bagi masyarakat. Di samping hasil survei juga didukung dengan penyelenggaraan konferensi yang diwakili oleh seluruh kelompok masyarakat di Karenni (Soe, 2014)

\section{Etika Diskursus}

Etika diskursus merupakan teori moral yang dikenalkan oleh Jurgen Habermas seorang filsuf dan ilmuwan sosial Jerman terkemuka saat ini 
bersama koleganya Karl-Otto Apel. Etika diskursus tidak menjawab pertanyaan mengapa kita bertindak moral. Dengan perkataan lain etika diskursus tidak menghasilkan jawaban-jawaban yang siap pakai terhadap pertanyaanpertanyaan moral. Apa yang ingin dipertanyakan dalam etika diskursus yaitu tentang "apa yang adil".

Etika diskursus dirumuskan dalam dua prinsip, pertama, yakni prinsip universalitas $(U)$, yang mengatakan, "All affected can accept the consequences and the side effect its general observance can be anticipated to have for the satisfaction of everyone's interest." (Habermas, 2007). Artinya, seluruh akibat yang dapat diterima dari konsekuensi-konsekuensi dan akibat samping yang secara umum dari pengamat (subyek) dapat diantisipasikan untuk memuaskan kepentingan bagi semua orang. Prinsip ini merupakan pertimbangan rasional yang mendalam dari seseorang mengenai problem moral sehingga mendapat keyakinan prinsip bahwa pertimbangan moral yang diputuskan akan berlaku umum bagi setiap orang pada kasus dan konteks yang sama. Prinsip ini menyatakan bahwa pertimbangan moral yang saya kehendaki akan berlaku benar kalau dikehendaki oleh semua orang.

Kedua, prinsip diskursus (D) yang berbunyi, " Only those norms can claim to be valid that meet (or could meet) with the approval of all affected in their capacity as participants in a practical discourse". Etika diskursus tidak berhenti pada tahap (U), maksudnya bahwa pertimbangan rasional itu tidak hanya berhenti pada subyek saja tetapi kebenaran yang dianggapnya universal itu perlu didiskursuskan untuk mencapai konsesus atau saling pengertian. Dengan demikian, hanya norma yang telah dipastikan dalam diskursus praktis dimana semua yang bersangkutan terlibat dapat dipastikan kebenarannya.

Habermas sendiri menerapkan etika diskursus untuk bidang hukum dan politik. Pemikiran Habermas ini digunakan Hardiman (2009) dalam penelitiannya ditawarkannya sebuah model bagi praktik demokrasi dan negara hukum pasca-Soeharto dalam masyarakat Indonesia. Dengan bantuan teori diskursus Habermas dapat digarap secara intensif prinsipprinsip, norma-norma dan kondisi-kondisi negara hukum modern dan politik demokratis di dalam masyarakat majemuk dewasa ini.

Etika diskursus juga diterapkan untuk bidang pendidikan, seperti yang ditulis oleh Jenlink (2014), hasil penelitiannya menunjukan bahwa etika diskursus menjadi penting dalam desain sistem pendidikan. Kesimpulan ini diambil setelah menguji etika diskursus sebagai sikap yang diambil oleh pengguna dan perancang yang terlibat secara kritis, reflektif dan secara sadar dalam sebuah penelitian untuk sebuah proyek pemahaman diri - menyadari "diri" individu dan sosial melalui keterlibatan secara otentik.

Di antara para pemikir terdapat mereka yang tidak menyetujui pemikiran Habermas, misalnya Powel (2009) - dalam tulisannya dengan judul Discourse Ethics dan Moral Rasionalisme menyangsikan apakah etika pemikiran Habermas ini dapat memberikan kepada kita sebuah upaya yang menunjukan bahwa moralitas adalah kebutuhan rasional. Jawaban yang diberikan olehnya adalah "tidak dapat", alasannya karena etika diskursus tidak dapat menghindarkan komitmennya pada prinsip-prinsip moral.

Pemikiran yang secara menyolok menentang pemikiran etika diskursus adalah apa yang dikenal dengan pemikiran tentang etika disensus. Kalau dalam etika diskursus "apa yang adil" dapat dicapai dengan konsesus atau kesepakatan, tetapi dalam etika disensus, konsesus itu tidak diperlukan. Menurut Diprose (2010) etika disensus berkaitan dengan antagonisme yang seharusnya menjadi perhatian bagi teori demokrasi. Dikatakan lebih lanjut bahwa etika disensus didasarkan atas kontestasi daripada asimilasi perbedaan.

Meskipun beberapa pemikir menentang konsesus, tetapi posisi penulis sendiri berpihak pada pemikiran etika diskursus karena penulis anggap relefan untuk menyelesaikan problem tentang keadilan dalam masyarakat Indonesia 
yang majemuk. Dalam kemajemukan masyarakat Indonesia tampaknya tidak mungkin membiarkan masing-masing kelompok untuk tetap berbeda tanpa mempunyai komitmen terhadap konsesus antara mereka. Untuk kasus masyarakat majemuk seperti di Indonesia paham disensus tampaknya akan membuka jurang perbedaan yang semakin menajam.

Di dalam masyarakat Indonesia etika diskursus lebih dikenal dengan istilah "musyawarah". Oleh karena itu, etika diskursus mempunyai kesesuaiannya dengan budaya dalam masyarakat Indonesia sehingga mudah diterima dan dipahami. Selain itu etika diskursus sesuai dengan kondisi sosial dan budaya masyarakat dewasa ini. Hardiman (2009) mengatakan dalam etika diskursus berpijak pada pluralitas cara hidup dan orientasi masyarakat modern sangat cocok untuk masyarakat Indonesia pasca-Soeharto yang ingin mengedepankan hukum dan hak-hak asasi manusia dalam proses demo-kratisasi dan reformasi.

Etika diskursus cocok untuk masyarakat yang pluralistik digambarkan Habermas dalam tulisannya Beetween Facts and Norms, etika diskursus mengacu pada pandangan dan keadilan universal yang mempunyai perspektif bebas dari seluruh egosentrisme dan etnosentrisme, etika politik diskursus mencari pemahaman diri yang otentik dari sebuah komunitas tertentu (Baumeister, 2003).

Di satu sisi masing-masing komunitas budaya dalam masyarakat Indonesia yang plural mempunyai keyakinan, kepercayaan, pandangan serta nilai-nilai sosial dan budaya yang berbeda-beda. Di sisi lain terdapat pengaruh modern yang mengakibatkan pandangan tradisional tidak dapat lagi memadai untuk menjamin warga masyarakat untuk hidup bersama dengan cara yang sesuai. Karena itu, etika diskursus diperlukan untuk memastikan kembali persoalan-persoalan yang dipertanyakan keberlakuannya dalam masyarakat Indonesia yang plural. Etika diskursus memberikan prosedur yang memadai untuk penyelesaian persoalan pelestarian budaya berdasarkan kriteria "apa yang baik" dan "apa yang adil".

Di era reformasi dimungkinkan setiap etnis dan kelompok masyarakat Indonesia bebas untuk mengungkapkan ekspresi budaya mereka masing-masing. Setiap ekspresi budaya dalam masyarakat mendapat tempat dan penghargaan tetapi sebaliknya tidak jarang menimbulkan persoalan sosial. Ekspresi kebebasan budaya sebagai penguatan identitas budaya kadang dipandang menjadi masalah bagi identitas budaya masyarakat lain. Komunikasi di antara kelompok etnis seringkali tidak terjalin dengan baik, sehingga menimbulkan konflik antar budaya. Dalam masyarakat Indonesia yang plural tersebut, masing-masing kepentingan budaya yang berbeda seringkali berbenturan, dalam situasi tersebut etika diskursus sangat diperlukan, sebagai sarana untuk mencapai saling pengertian.

\section{METODE}

Penelitian ini menggunakan pendekatan kualitatif dengan metode studi kasus, yakni memperdalam kasus adaptasi aksara Korea menjadi aksara Ciacia. Penelitian juga didukung dengan studi pustaka. Penelitian berlokasi di Kota Baubau, Buton, Sulawesi Tenggara sebagai tempat terjadinya kasus adaptasi aksara Korea. Waktu penelitian diselenggarakan selama tujuh hari dari tanggal 15 sampai dengan 21 Desember 2013.

Pengumpulan data dilakukan dengan melakukan wawancara secara mendalam dengan informan yang terkait dengan upaya adaptasi aksara Korea, antara lain: para guru yang mengajar aksara Korea; peserta didik yang mendapat pengajaran aksara Korea; parabela (ketua adat) yang telah menyetujui atau menandatangani perjanjian penggunaan aksara Ciacia; para peneliti bahasa dari Kantor Bahasa Provinsi Sulawesi Tenggara; ahli bahasa Ciacia dari perguruan Tinggi Negeri; pejabat pemerintah seperti Dinas Pendidikan Propinsi, Dinas Kebudayaan dan Pariwisata Kota; serta anggota 
dewan. Wawancara dilakukan pula dengan tokoh muda Ciacia yang berasal dari luar Kota Baubau; serta masyarakat Kota Baubau.

Setelah data terkumpul, langkah berikutnya melakukan identifikasi dan kategorisasi dari pendapat-pendapat yang pro dan yang kontra terhadap adaptasi aksara Korea. Selanjutnya dilakukan analisis terhadap pendapat-pendapat yang pro dan kontra itu berdasarkan atas motifmotif dan alasan-alasan, mengapa mereka setuju dan tidak menyetujui adaptasi. Analisis ini melihat sejauh mungkin perspektif etika diskursus, yakni upaya untuk tercapainya konsesus yang adil dengan melibatkan mereka yang berkepentingan dalam suasana saling pengertian.

\section{HASIL DAN PEMBAHASAN}

\section{Adaptasi Aksara Korea: Antara yang Pro dan Kontra}

Kebijakan pemerintah Kota Baubau untuk mengadaptasi aksara Korea menjadi aksara Ciacia ditindaklanjuti dengan himbauan Walikota untuk mendokumentasikan budaya masyarakat Ciacia dengan aksara Ciacia. Melalui sarana dan pemanfaatan aksara yang baru ini, maka bahasa, karya sastra, cerita rakyat, sejarah dan budaya masyarakat Ciacia diharapkan dapat didokumentasikan dengan baik. Beberapa papan nama jalan di kecamatan Sorawolio ditulis dengan aksara Korea. Pemerintah Kota Baubau juga telah melakukan kebijakan pembelajaran aksara Ciacia yang notebene aksara Korea itu untuk masuk dalam kurikulum muatan lokal. Pembelajaran muatan lokal telah dilaksanakan di dua Sekolah Dasar di Sorawolio dan Bugi.

Seiring dengan adaptasi aksara Korea menjadi aksara Ciacia, telah dibuka wacana ilmiah, antara lain untuk mendiskusikan upaya pelestarian bahasa daerah, seperti Kongres Internasional, Bahasa-Bahasa Daerah Sulawesi Tenggara pada Juli 2010, di Sulawesi Tenggara. Di dalam kertas kerjanya Tamin (2010) menyatakan bahwa terdapat dua pandangan yang saling bersaing dan menunjukan posisi pikiran masing-masing. Kelompok pertama melihat bahwa kebudayaan sebagai sesuatu yang statis. Pandangan ini ingin mempertahankan nilai-nilai asli, Kelompok ini cenderung anti-perubahan dan tidak bersedia menerima halhal yang baru. Sebaliknya, kelompok kedua berpandangan bahwa kebudayaan berjalan dinamik dan terus berdialektika sepanjang sejarah. Kebudayaan terus berkembang agar tidak mengalami kepunahan.

Kebijakan penggunaan aksara Ciacia yang baru itu telah memunculkan perbedaanperbedaan pandangan antara yang pro dan kontra. Masing-masing mengklaim mempunyai tujuan yang sama, yakni ingin melestarikan bahasa Ciacia. Di antara yang pro mempunyai alasan. Pertama, bahwa budaya tidak statis tetapi terus berkembang, bahasa juga berkembang. Mereka berargumen bahwa adaptasi aksara Korea menjadi aksara Ciacia itu sangat dimungkinkan, seperti dinamika yang terjadi pada masa lalu juga terjadi adaptasi aksara Arab menjadi aksara Buri Wolio - aksara yang digunakan untuk menuturkan bahasa Wolio. Kenyataannya dengan adaptasi aksara Arab tidak membuat masyarakat mempunyai identitas budaya Arab. Kedua, aksara Ciacia yang diadaptasi dari aksara Korea tidak akan mengubah bahasa Ciacia karena yang diadaptasi hanya aksara saja tidak akan mempengaruhi budaya masyarakatnya. Ketiga, penggunaan aksara Ciacia merupakan upaya untuk mencegah kepunahan bahasa Ciacia sehingga dapat diwariskan kepada generasi berikutnya. Penggunaan aksara ini dapat memicu supaya generasi muda dapat meminati bahasa daerah Ciacia.

Kelompok yang setuju terhadap adaptasi aksara Korea ini, antara lain tokoh adat dua suku yang menggunakan bahasa Ciacia yaitu Laporo dan Kaisabu di Kecamatan Sorawolio. Para tokoh adat secara langsung menandatangani berita acara persetujuan penggunaan aksara Hangeul dalam Bahasa Ciacia Laporo dan Ciacia Kaisabu di Kecamatan Sorawolio. Para birokrat pada umumnya setuju dengan adaptasi aksara Korea, salah satu informan di jajaran 
birokrasi pemerintah Kota Baubau mengatakan: "adaptasi ini memberikan dampak positif, dan seharusnya masyarakat berterima kasih kepada orang Korea yang mengajarkan dan memberikan pengetahuan bahasa Korea di Kota Baubau ini dengan ikhlas. Dampak positif lainnya, yaitu beberapa pemuda dan pemudi di Kota ini mendapat kesempatan berkunjung ke Korea Selatan untuk melihat dari dekat tentang budaya Korea Selatan. Hal yang positif lagi adalah teman-teman Korea memberikan sumbangan dalam dunia pendidikan yaitu bantuan komputer ke sekolah-sekolah. Untuk saya pribadi lebih mengambil sisi positifnya teman-teman dari negara Korea Selatan banyak memberikan sisi positif mereka menampilkan kebudayaan, tarian yang mereka bawakan adalah budaya tradisional. Mereka tidak malu-malu menampilkan alat tradisional (anonim, wawancara, 20 Desember 2013).

Kelompok masyarakat yang setuju terhadap adaptasi di antaranya ialah para guru, dan murid-murid yang secara langsung merasakan dampak kebijakan yang dinilai positif; sehingga pada umumnya mereka bersikap mendukung adaptasi, kendati tidak seluruh aspek disetujuinya. Salah seorang guru yang mengajarkan aksara Korea di salah satu sekolah Dasar Negeri di Sorawolio, mengatakan: "bayangkan dulu perjuangan Raja Sejong untuk menciptakan Hungeul dengan perjuangan yang keras, sekarang kita tidak mencuri aksara itu tetapi diberikan oleh mereka". Dari keterangan yang disampaikan tersebut dapat dipastikan bahwa sikapnya mendukung adaptasi aksara Korea (anonim, wawancara, 18 Desember 2013).

Di sisi lain, kelompok yang memiliki pandangan yang menolak adaptasi aksara Korea, beralasan: pertama, masuknya aksara Korea ke dalam bahasa Ciacia justru mengakibatkan percampuran bahasa antara bahasa Ciacia dan Bahasa Korea, yang akhirnya akan diikuti oleh masuknya kosa kata dan istilah bahasa Korea dalam bahasa Ciacia. Kedua, sebaiknya aksara yang lebih tepat untuk diadaptasi sesuai dengan konteks sejarah dan budaya masyarakat Ciacia, yakni aksara Buri Wolio. Masyarakat Ciacia tentu lebih mudah menggunakan aksara Buri Wolio karena relasi sosial masyarakat Ciacia sangat intens dengan masyarakat yang berbahasa Wolio. Aksara Buri Wolio pun akan mudah dipelajari oleh anak-anak karena mereka mempunyai kebiasaan mengaji. Ketiga, aksara Buri Wolio telah mengakar, melalui sebuah proses sejarah dan akulturasi yang panjang dalam konteks kehidupan sosial dan masyarakat Buton. Adaptasi aksara Arab melalui proses yang tidak instan tetapi didasarkan atas kebutuhan komunikasi masyarakat pada masa lalu, bukan karena kebijakan dari penguasa yang diperuntukan untuk masyarakatnya. Keempat, keputusan penggunaan aksara Ciacia tidak melibatkan penutur bahasa Ciacia lainnya, seperti di Kabupaten Wakatobi, Kabupaten Wabula, dan tempat lainnya yang tersebar di Indonesia.

Kelompok yang tidak setuju terhadap kasus adaptasi aksara Korea, di antaranya seorang pakar linguistik dari Baubau. Dikatakanya bahwa "kebijakan untuk mengadaptasi aksara Korea tidak tepat karena tidak sesuai dengan kultur masyarakat Ciacia. Tradisi dan budaya masyarakat Ciacia adalah budaya Wolio, bahasa induknya adalah bahasa Wolio" (anonim, wawancara, 16 Desember 2013).

Berdasarkan basis keilmuan yang dimiliki para ahli linguistik umumnya tidak setuju dengan adaptasi aksara Korea. Pendapat ini diperkuat dengan pernyataan seorang peneliti dari Kantor Bahasa Provinsi Sulawesi Tenggara: "adaptasi aksara Hungeul ini dilakukan dengan tidak secara alamiah, tetapi disengaja. Apa yang ditawarkan oleh tokoh masyarakat Buton sendiri (di luar Kota Baubau) memberikan solusi mengapa tidak mengambil bahasa Buri Wolio, kalau bahasa Wolio akan mudah diajarkan pada anak-anak, karena mereka sudah terbiasa mengaji" (anonim, wawancara, 16 Desember 2013).

Pendapat yang tidak setuju terhadap adaptasi dinyatakan juga oleh seorang informan dari tokoh pemuda Ciacia yang tinggal di luar Kota Baubau. "Kalau dalam kegiatan pertunjukan 
seni dengan Korea tidak menjadi masalah, tetapi kalau aksara mengapa kita tidak menggunakan aksara Wolio, karena Ciacia adalah bagian dari Wolio", begitu katanya (anonim, wawancara, 20 Desember 2013).

\section{Penyelesaian Etika Diskursus}

Kerjasama antara Pemerintah Kota Baubau dengan pihak Korea Selatan tidak hanya sebatas adaptasi aksara Korea saja, tetapi diperluas menjadi rencana pendirian Korean Baubau Center bekerja sama dengan Hunminjeounggem Society of Korea (HSK). Upaya kerjasama dengan luar negeri ini menunjukan bahwa daerah mempunyai kebebasan untuk mengembangkan daerahnya sebagai wilayah desentralisaasi. Dalam sistem kekuasaan yang terdesentralisasi dan dalam dinamika Indonesia yang demokratis saat ini maka persoalan tentang wewenang dapat didiskursuskan. Dalam sistem desentralisasi daerah otonom mempunyai wewenang untuk mengatur dan mengurus urusan pemerintahan sendiri dalam koridor sistem Negara Kesatuan Republik Indonesia. Terkait dengan persoalan pelestarian budaya, negara mengakui dan menghormati kesatuan-kesatuan masyarakat hukum adat beserta hak tradisionalnya sesuai dengan perkembangan masyarakat. Pada masa Orde Baru kerja sama daerah dengan luar negeri dapat dipastikan tidak mungkin, karena pusat akan melakukan kontrol yang sangat ketat. Di dalam kasus adaptasi aksara Korea menjadi aksara Ciacia sebagai kebijakan pemerintah Kota Baubau, merupakan kewenangan daerah dan sebagai kewajiban daerah untuk melestarikan kebudayaan daerahnya masing-masing. Namun, dalam kondisi pelestarian dipertanyakan oleh beberapa pihak maka kebijakan ini perlu dikaji ulang.

Di Korea sendiri adaptasi ini telah diekspose oleh beberapa media Korea antara lain, Yonhap News Agency (26 Juli 2010) mengutip pendapat Amirul Tamin, bahwa pemerintah Indonesia telah menyetujui penggunaan huruf Korea sebagai huruf resmi suku Ciacia. Di sebutkan pula pernyataannya dalam tulisan: "meskipun prihatin atas pengaruh budaya dari luar negeri, pemerintah Indonesia akhirnya memutuskan untuk mengakui Hangeul sebagai sistem penulisan resmi untuk melestarikan bahasa minoritas yang terancam punah".

Kedutaan Besar Republik Indonesia di Seoul merespon pemberitaan media Korea ini dengan mengirimkan surat faksimili kepada Menteri Luar Negeri dan Menteri Pendidikan Nasional up. Kepala Pusat Bahasa di Indonesia untuk meminta klarifikasi tentang pernyataan Walikota Baubau karena banyak pertanyaan dari berbagai pihak. Kantor Pusat Bahasa sebagai lembaga pemerintah Indonesia yang mempunyai wewenang terhadap masalah kebahasaan telah menanggapi persoalan ini yang tertuang dalam dua belas butir tanggapan sebagai respon atas pemakaian aksara Korea dalam Bahasa Ciacia. Sedangkan, pemerintah Korea sendiri enggan mendukung proyek the Hunmin Jeongeum Society karena khawatir akan merusak hubungan diplomatik dengan Indonesia.

Di dalam negeri Indonesia adaptasi aksara Korea menjadi pertanyaan kritis bagi penggunanya, yakni masyarakat Ciacia yang terkena dampak dari pemberlakuan aksara Korea. Pertanyaan kritis dilakukan terutama di luar Kota Baubau seperti Kabupaten Wabula dan Kabupaten Wakatobi. Mereka merasa tidak dilibatkan dalam pengambilan kebijakan adaptasi tersebut.

Menurut undang-undang otonomi daerah yang punya wewenang untuk mengurus kasus ini adalah pemerintah daerah. Penyelesaian persoalan dalam pelestarian kebudayaan antar pemerintah kabupaten/kota dalam satu provinsi dan antar provinsi telah diatur dalam Peraturan Bersama Menteri Dalam Negeri dan Menteri Kebudayaan dan Pariwisata nomor 42 dan 40 tahun 2009, bahwa penyelesaian pelestarian kebudayaan diselesaikan secara musyawarah. Kebijakan pelestarian budaya di tingkat lokal berada ditangan pemerintah daerah, namun ketika norma moral dipertanyakan maka disitulah 
pentingnya etika diskursus yang melibatkan seluruh partisipan yang terkena dampak atas kebijakan tersebut.

Aksara Ciacia telah diberlakukan dalam lingkup masyarakat Ciacia di Kota Baubau, khususnya dua masyarakat Ciacia Laporo dan Ciacia Kaisabu di Kecamatan Sorawolio. Tokoh adat mereka telah menyetujui penggunaan aksara Hangeul dalam bahasa Ciacia Laporo dan Ciacia Kaisabu. Meskipun telah disetujui oleh tokoh masyarakat, persetujuan ini secara kultural kurang mengakar karena inisiatif adaptasi itu berasal dari penguasa daerah setempat. Kebutuhan untuk mengadaptasi bukan karena kebutuhan dalam konteks pelestarian budaya, tetapi lebih karena konteks sosial dan ekonomi. Seperti yang dikatakan oleh Song (2013) dalam penelitiannya bahwa tidak dapat dipungkiri bahwa proyek Hangeul mempunyai motif kepentingan ekonomis untuk menarik investasi Korea terhadap kota ini dengan melakukan pertukaran budaya. Pada masa pemerintah Soeharto kerjasama dengan pihak asing tidak akan mungkin terjadi karena daerah hanya menerima proyek pembangunan nasional dari pemerintah pusat.

Bertolak dari persoalan pro dan kontra tersebut, perlu dilihat dalam perspektif etika diskursus. Masing-masing pihak perlu membuka diri secara bersama memperbincangan persoalan pelestarian aksara Ciacia untuk mencapai saling pengertian. Penyelesaian etika diskursus tampak seperti ditawarkan oleh Kantor Bahasa Provinsi Sulawesi Tenggara (Hanna, 2010) yang menanggapi: "Penggunaan dan penerimaan aksara Hanguel untuk menjadi bagian dari budaya Indonesia harus melalui penelitian dan kajian yang mendalam. Hasil kajian dan penelitian tersebut kemudian perlu dipaparkan dan dipertanggungjawabkan di depan publik melalui forum resmi dan ilmiah, baik melalui kongres, seminar maupun simposium, sehingga dapat diterima oleh semua kalangan. Rekomendasi yang dihasilkan dalam forum tersebut dapat diajukan kepada lembaga-lembaga terkait, diantaranya Kementerian Dalam Negeri,
Kementerian Pendidikan Nasional, atau Kementerian Kebudayaan dan Pariwisata untuk memperoleh legitimasi di DPR/DPRD agar aksara tersebut dapat dipergunakan dalam berbagai aktivitas kemasyarakatan".

Pernyataan tersebut memperlihatkan bahwa problem yang menyangkut persoalan pelestarian aksara yang diberlakukan itu harus dapat dipertanggungjawabkan secara rasional, kebenarannya harus dapat berlaku universal (U) dapat diterima oleh semua orang karena didasarkan penelitian dan kajian yang cukup mendalam dan komprehensif. Penelitian perlu dilakukan secara obyektif, dalam pengertian ditujukan untuk kepentingan pelestarian demi pelestarian itu sendiri, yakni pelestarian yang berkeadilan demi meningkatkan harkat dan martabat pendukung budaya yang bersangkutan. Bukan ditujukan untuk kepentingan rasionalitas sasaran, agar sasaran yang diinginkan itu dapat tercapai.

Pemberlakuan aksara Ciacia harus dapat diterima oleh seluruh kalangan, yang terkait dengan penggunaan aksara Ciacia. Prinsip diskursus ini seperti tampak dalam tanggapan Kantor Bahasa Provinsi Sulawesi Tenggara (Hanna 2010) menyatakan: "Penggunaan aksara Hangeul dalam Bahasa Ciacia perlu melibatkan masyarakat khususnya penutur bahasa Ciacia yang tersebar di seluruh penjuru wilayah Kota Bau-Bau, Kabupaten Buton, dan Kabupaten Wakatobi, bukan hanya dari pengambil dan penentu kebijakan semata. Kebijakan penggunaan aksara Hangeul (Korea) terlalu terburuburu. Kebijakan ini diambil tanpa melalui survei dan penelitian yang mendalam mengenai keberterimaan masyarakat bahasa Ciacia terhadap aksara Hangeul".

Prinsip diskursus (D) dapat diperlihatkan dengan melakukan diskursus untuk mencapai konsesus diantara partisipan, yakni masyarakat Ciacia sebagai pendukung budaya Ciaca untuk mencapai kesepakatan menerima atau menolaknya. Karena itu hanya norma yang telah dilaksanakan berdasarkan diskursus praktis adalah norma yang dapat diakui kebenarannya. 
Berdasarkan prinsip ini berarti pertimbangan pelestarian Ciacia yang telah dilakukan penguniversalan $(U)$ hendaknya dapat dilakukan diskursus praktis. Peserta diskursus adalah pihak-pihak yang terikat dengan keberaksaraan Ciacia, tidak hanya di Kota Baubau saja, tetapi diskursus praktis perlu melibatkan masyarakat Ciacia di luar Kota Baubau. Tampaknya kasus adaptasi aksara Korea ini belum sampai melibatkan diskursus praktis yang mana semua pihak yang terikat dengan keberaksaraan Ciacia dilibatkan untuk mencapai saling pengertian.

Di dalam diskursus praktis itu ruang publik menjadi penting. Persoalan ruang publik ditulis oleh Habermas dalam karyanya yang berjudul The Structural Transformation of the Public Sphere: An Inquiry into a Category of Bourgeouis Society. Ruang publik bukanlah merupakan tempat tetapi sebuah kondisi atau syarat yang memungkinkan terjadinya intersubyektifitas dalam sebuah pembicaraan bersama. Dalam disertasinya Seran (2009) menjelaskan konsep ruang publik itu sebagai medan "pertempuran" pelbagai kepentingan masyarakat, ekonomi, dan politik yang harus diselesaikan menurut sebuah prosedur rasional yang terlaksana dengan melibatkan semua pihak yang bebas dan terbuka dalam pembicaraan bersama. Kasus adaptasi aksara Korea tidak sepenuhnya dibuka ruang publik untuk para anggota masyarakat Ciacia agar dapat berpartisipasi menentukan kebijakan pemerintah Kota Baubau yang terkait dengan budaya Ciacia. Kasus adaptasi ini menjadi monologal, tidak terjadi intersubyektifitas diantara anggota masyarakat Ciacia. Keputusan adaptasi lebih berasal dari penguasa pemegang kebijakan pada waktu itu.

\section{SIMPULAN DAN SARAN}

\section{Simpulan}

Berdasarkan uraian di atas dapat disimpulkan dua hal terkait dengan adaptasi aksara Korea menjadi aksara Ciacia. Pertama, dalam upaya pelestarian bahasa Ciacia dengan cara mengadaptasi aksara Korea itu terdapat dua kubu yang saling bersaing, masing-masing mengklaim bahwa pandangannya sebagai upaya untuk melestarikan bahasa Ciacia supaya tidak mengalami kepunahan. Pihak yang setuju lebih berorientasi pada rasionalitas instrumental, yakni upaya pelestarian dimaksudkan untuk mencapai sasaran yang bersifat ekonomis dan politis, sedangkan pihak yang tidak setuju lebih mempertimbangkan pelestarian bahasa Ciacia sendiri sebagai sebuah kultur. Kedua, dalam situasi di mana dua pandangan bersaing maka etika diskursus diperlukan, untuk mencari kesepakatan dan saling pengertian, dalam menyelesaikan persoalan secara baik dan adil. Etika diskursus memeriksa apakah sebuah pandangan itu dapat dipertahankan secara rasional, yakni dalam situasi tanpa tekanan sehingga sebuah norma dapat diberlakukan secara universal. Dalam kasus pelestarian aksara Ciacia, telah dilakukan penelitian secara ilmiah namun di sisi lain diperlukan dialog untuk menguji kebenaran dari penelitian ilmiah tersebut. Selanjutnya, diskursus praktis diperlukan dari masing-masing pihak yang terkait dengan pelestarian aksara Ciacia untuk melakukan konsesus, berdasarkan atas saling pengertian, dengan membuka dialog bersama masyarakat Ciacia baik di dalam dan di luar Kota Baubau. Hasil konsesus ini dapat menjadi rekomendasi DPR/DPRD untuk membuat kebijakan terkait dengan pelestarian aksara Ciacia. Dalam kasus ini, ruang dialog terhadap masyarakat yang terkena dampaknya belum pernah dilakukan, karena itu penggunaan aksara Ciacia masih menjadi perdebatan.

\section{Saran}

Etika diskursus dapat menjadi prosedur untuk menyelesaikan persoalan-persoalan yang terkait dengan pelestarian budaya secara baik dan adil. Pemerintah pusat dan daerah selayaknya membuka saluran-saluran ruang publik untuk menyampaikan pendapat yang bebas dari tekanan dari pihak manapun sebagai kekuatan 
untuk menyelesaikan persoalan pelestarian budaya. Ruang publik memerlukan pelibatan masyarakat dalam pengambilan kebijakan di bidang kebudayan, seperti yang dikenal dengan budaya musyawarah yang sudah dijalankan sejak lama oleh masyarakat Indonesia.

\section{PUSTAKA ACUAN}

Alirman, L. O. Juli 2010. Dialektika dan Kebijakan Keberaksaraan di Kota Baubau. Paper dipresentasikan pada Kongres Internasional Bahasa-Bahasa Daerah Sulawesi Tenggara. Hanna, Firman AD, dan Sandra Safitri (Editor). Sulawesi Tenggara: Kantor Bahasa Provinsi Sulawesi Tenggara, Pusat Bahasa, Kementerian Pendidikan Nasional.

Baumeister, A Y. 2003. Habermas: Discourse and Cultural Diversity. Journal Political Studies, (51), hlm. 740-758.

Davis, C. 2013. Language preservation. Journal Diverse Issues in Higher Education. 30(13), 7.

Diprose, R. 2010. Dissensus, Melancholic Nationalism, And Biopolitics in The Work of Ewa Ziarek. Philosophy Today. Spep Supplement 2010: 43-50.

Elis, A. 2005. Minority Right and The Preservation of Language. Philosophy, (80), hlm. 199-217

Habermas, J. 2007. Moral Consciousness and Communicative Action. Translate by Christian Lenhardt and Shierry Weber Nicholsen. USA: Polite Price.

Hanan, S. S. 2014. Genealogi Bahasa Ciacia. Disertasi. Yogyakarta: Program Pasca Sarjana Ilmu Budaya, UGM

Hanna. 2010. Tanggapan Kantor Bahasa Provinsi Sulawesi Tenggara terhadap Jawaban Surat Pemerintah Kota Baubau mengenai Pemakaian Aksara Korea dalam Bahasa Ciacia. Sulawesi Tenggara: Kantor Bahasa Sulawesi Tenggara.

Hardiman, B. F. 2009. Demokrasi Deliberatif, Menimbang "Negara Hukum" dan "Ruang Publik" dalam Teori Diskursus Jurgen Habermas. Publikasi Penelitian. Yogyakarta: Penerbit Kanisius.

Instruksi Presiden Republik Indonesia Nomor 14 tahun 1967 tentang Agama Kepercayaan dan Adat Istiadat Cina. http://www.hukumonline.com/pusatdata, diakses 30 Juli 2015.

Jenlink, P. M. 2014. Discourse Ethics in the Desain of Educational System: Consideration for Desaign Praxis. Research Paper. Publised online in Wiley Inter Science.

Jones, T. 2005. Indonesian Cultural Policy, 1950-2003, Culture, Institution, Government. The Thesis for the Degree of Doctorat pf Philosophy. Australia: Departemen of Media and Information Faculty of Media, Society, and Culture, Curtin University of Technology.

Kusumohamidjojo, B. 2009. Filsafat Kebudayaan, Proses Realisasi Manusia. Yogyakarta: Jalasutra.

Peraturan Bersama Menteri Dalam Negeri dan Menteri Kebudayaan dan Pariwisata Nomor 42 dan 40 tahun 2009. http://www.hukumonline.com/pusatdata, diakses 3 Agustus 2015

Peraturan Menteri dalam Negeri 39 Tahun 2007 tentang Pedoman Fasilitas Organisasi Kemasyarakatan Bidang Kebudayaan, Keraton, dan Lembaga Adat dalam Pelestarian dan Pengembangan Budaya Daerah. https://portal.mahkamahkonstitusi.go.id. diakses 1 Agustus 2015

Powel, B. K. 2009. Discourse Ethics dan Moral Rasionalisme. Journal Dialog-Canadian, Philosopical Association, (48), hlm. 374-386. 
Serafín, C.M.M. 2008. Language Ideologies of the High Academy of the Quechua Language in Cuzco, Peru. Journal. Latin American and Caribbean Ethnic Studies, 3(3), hlm. 319-340.

Seran, A.2010. Etika Diskursus Jurgen Habermas Sumbangan bagi Pemahaman Undang-Undang Dasar 1945 dan Hubungannya dengan Pancasila. Disertasi. Jakarta: Universitas Indonesia.

Soe, P. 12 September 2014. Karenni Language, Alphabet to be Taught in Schools. Democratic Voice of Burma. http://e-sources.perpusnas.go.id. diakses 25 Juli 2015.

Song, W. S. 2013. Being Korean in Buton? The Cia-Cia's Adoption of The Korean Alphabet and Identity Politics in Decentralized Indonesia. Jurnal KEMANUSIAAN, 20(1), hlm. 51-80

Surat Edaran Kabinet Ampera No. 6 tahun 1967, https://id.wikisource.org/wiki/ Surat_Edaran_Presidium_Kabinet_Ampera_Nomor_06_Tahun_1967, diakses 1 Agustus 2015.

Tamin, A. Juli 2010. Dialektika dan Kebijakan Keberaksaraan di Kota Baubau. Paper dipresentasikan pada Kongres Internasional Bahasa-Bahasa Daerah Sulawesi Tenggara. Hanna, Firman AD, dan Sandra Safitri (Editor). Sulawesi Tenggara: Kantor Bahasa Provinsi Sulawesi Tenggara, Pusat Bahasa, Kementerian Pendidikan Nasional.

Yonhap News Agency. 26 Juli 2010. ejkim@yna.co.kr. Indonesia OKs Minority Tribe's use of Korean Alphabet. http://english.yonhapnews.co.kr/ diakses 15 September 2014. 